Article

\title{
Evaluation of Hydrological Alterations at the Sub-Daily Scale Caused by a Small Hydroelectric Facility
}

\author{
Camila C. Braun-Cruz ${ }^{1}$, Hans Mario Tritico ${ }^{2}$, Renato Leandro Beregula ${ }^{3}{ }^{\circledR}$, Pierre Girard ${ }^{1}{ }^{1}$, Peter Zeilhofer ${ }^{1}$, \\ Letícia de Souza Ribeiro ${ }^{3}$ and Ibraim Fantin-Cruz ${ }^{1, *(\mathbb{D})}$ \\ 1 Program in Water Resources, Federal University of Mato Grosso, Cuiabá 78060-900, Brazil; \\ camilacarolinebraun@gmail.com (C.C.B.-C.); pierregirard1301@gmail.com (P.G.); \\ zeilhoferpeter@gmail.com (P.Z.) \\ 2 School of Engineering, University of Mount Union, Alliance, OH 44601, USA; tritichm@mountunion.edu \\ 3 Department of Sanitary and Environmental Engineering, Federal University of Mato Grosso, \\ Cuiabá 78060-900, Brazil; renato.beregula@gmail.com (R.L.B.); leticiasouza.ribeiro.ls@gmail.com (L.d.S.R.) \\ * Correspondence: ibraimfantin@gmail.com
}

check for updates

Citation: Braun-Cruz, C.C.; Tritico, H.M.; Beregula, R.L.; Girard, P.; Zeilhofer, P.; Ribeiro, L.d.S.;

Fantin-Cruz, I. Evaluation of Hydrological Alterations at the Sub-Daily Scale Caused by a Small Hydroelectric Facility. Water 2021, 13, 206. https://doi.org/10.3390/ w13020206

Received: 7 December 2020 Accepted: 13 January 2021 Published: 16 January 2021

Publisher's Note: MDPI stays neutral with regard to jurisdictional clai$\mathrm{ms}$ in published maps and institutional affiliations.

Copyright: (C) 2021 by the authors. Licensee MDPI, Basel, Switzerland. This article is an open access article distributed under the terms and conditions of the Creative Commons Attribution (CC BY) license (https:// creativecommons.org/licenses/by/ $4.0 /)$.

\begin{abstract}
This work aims to evaluate the hydrologic changes caused by a small hydropower plant on the watercourse in which it is installed. Since hydrologic research with data of temporal frequencies less than a day is less common than daily measurements, there are few indicators and methodologies capable of treating such records. For this reason, 17 indicators are proposed which describe the magnitude, duration, frequency and rate of changes in hydrologic conditions occurring in a watercourse at a sub-daily frequency. These 17 indicators were used to assess changes in the flow regimes at sub-daily scales across the Itiquira hydroelectric facility in Mato Grosso, Brazil. During the dry season the river was more susceptible to hydroelectric operations than during the wet season. Eighty-eight percent of the proposed indicators were significantly altered during the dry season compared to $71 \%$ during the rainy season. In addition to the number of indicators that changed between the seasons, the magnitude of the change was different. During the dry season, $53 \%$ of the magnitudes of the proposed indicators were classified as having a high magnitude of change, while in the rainy season only $6 \%$ of the indicators were characterized as having a high magnitude of change.
\end{abstract}

Keywords: run-of-river; hydropeaking; sub-daily hydrologic indicators; Pantanal

\section{Introduction}

Run-of-the-river hydroelectric facilities generate energy with minimal or no water accumulation capacity. In these hydropower plants, unlike large dams, there is minimal rainwater reserved for energy production during dry periods, leading to seasonal variations in production [1].

Over the last two decades, this model of hydraulic energy utilization has been accepted as one alternative to mitigate the socioenvironmental problems that accompany large reservoirs. Despite the fact that these projects are considered to be less environmentally impactful, the recent trend of installing multiple facilities in the same watercourse (cascading facilities) has the potential to lead to cumulative and synergistic impacts that are not yet well known [2,3].

In the same way that the hydrological regime affects the production of hydropower, its maintenance is of fundamental importance for the reproduction, feeding and growth of the aquatic biota, and should be maintained within natural patterns [4-6]. Several decades of studies have sought to characterize the conditions of the natural river flow and to quantify anthropogenic hydrological alterations. These studies have proposed several metrics [7,8], based on historical series with daily data, which describe ecologically relevant components of a river's hydrology. 
A well-known effect of larger hydroelectric dams is the release of water at variable rates over the course of the day (i.e., sub-daily) to accommodate variation in electricity demand. The resultant short-term variability in downstream velocity, discharge, and water levels is known as load following or hydropeaking [9]. However, in run-of-river plants, these short-term changes in flow tend to be more frequent than in larger facilities. Thus, more detailed information on flow variation over a shorter interval (hourly or subhourly) may be needed to identify impacts to biota. Some metrics that utilize sub-daily data have previously been proposed [10-15]. These studies show that the operations of reservoirs, even the small ones, have the potential to cause modifications to the sub-daily hydrological regime.

In Brazil, a discussion about the effects of the operation of small hydroelectric power plants on aquatic ecosystems has gained prominence in the Paraguay Hydrographic Basin (PHB); a basin that encompasses the Pantanal, the largest freshwater floodplain in the world. This biome is recognized as a World Heritage Site by UNESCO, and has three Ramsar Sites (Wetlands of International Importance). Despite its environmental and cultural relevance [16], there has been a recent expansion in the number of hydroelectric facilities in the basin; there are 47 installed hydroelectric plants and another 138 projects planned for installation [17].

Most of these new facilities are run-of-the-river arrangements with little storage capacity. For this reason, these types of facilities have been defended as the best model for the region, since they would not have the capacity to alter the flood pulse that defines the Pantanal hydrology [18]. The hydrological effects of the existing run-of-the-river facilities in the region, using metrics based on daily data, show that this argument is generally coherent since they concluded that the hydrological alterations identified are of low magnitude [2,19]. Given the unique characteristics of the region, the installation and operation of these facilities must be in line with the United Nation's Sustainable Development Goals, in order to promote actions that achieve sustainability for the region, as advocated by [20].

Figure 1 shows a typical structure found in $46 \%$ of hydropower plants in the PHB [21]. In this configuration there is a relatively small dam that retains enough water to ensure that water enters a diversion channel. The dam also typically has a spillway, which is capable of releasing the excess flow in the reservoir. The diversion route is composed of a low pressure conduit (this can be a channel or a free conduit), a forced conduit, a power house, and finally, a return channel that returns the diverted flow to the natural channel [22].

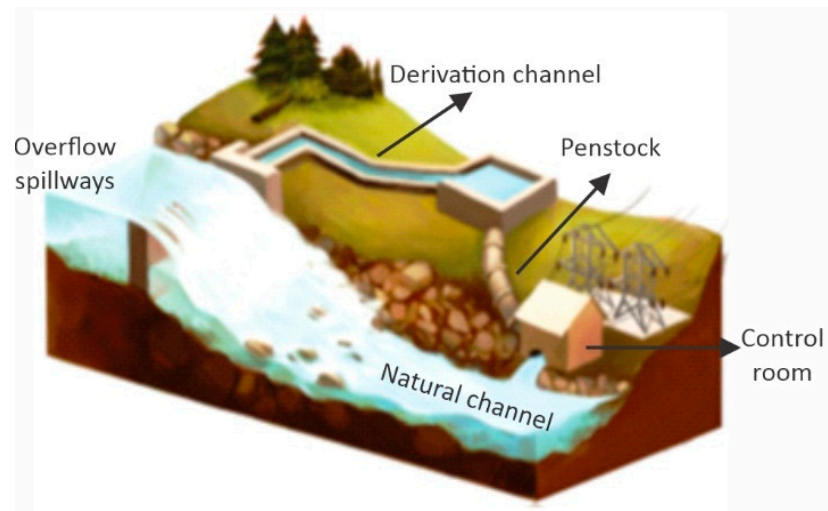

Figure 1. Typical arrangement of diversion channel hydroelectric facilities that are common in the Paraguay Hydrologic Basin. Adapted from [22].

The common metrics used for the purpose of assessing the hydrologic effects of reservoirs are based mainly on the use of daily or monthly flow data [23]. One of the metrics widely used for this purpose is the Indicators of Hydrologic Alteration (IHA) proposed by [7], which is based on a historical series with daily data for the calculation of 
its indicators. Since its publication, this metric has been shown to be an efficient tool with diverse applications, especially in reservoir operations [24].

Similarly [25] verified that daily averages are not sufficient to monitor the effects of water withdrawals occurring over short time periods (one to three hours). They also have the potential to be ineffective in the evaluation of impacts from small reservoirs, since these are dependent on turbine operations that occur over short time periods.

In this context, except for the studies by [2] and [26] which have large storage reservoirs, little is known about the effects of run-of-river hydroelectric operations on the Pantanal's hydrological regime, especially on the impacts of hydropeaking. This study's objective is therefore to evaluate whether the operation of a run-of-the-river hydroelectric facility affects the sub-daily hydrological regime of the downstream river. For this purpose, 17 hydrological indicators were proposed and used to describe the sub-daily hydrology upstream and downstream from a run-of-the-river facility.

\section{Methods}

\subsection{Sub-Daily Hydrological Indicators (SDHI)}

To quantify the hydrological alterations caused by hydroelectric projects, indicators were developed to describe the flow regime at a sub-daily scale. The aim was to develop indicators that build on the $33 \mathrm{Hydrologic}$ Change Indicators proposed by [7], which are based on daily data series of the annual hydrologic regime.

Seventeen indicators were developed for the application to data series with hourly measurement frequencies. These indicators include four of the five components used by [7] that describe the variability of the hydrological regime: magnitude, duration, frequency and rate of change of flow (Table 1). Among the indicators presented, four (daily range, duration of stability and duration of high and low pulses) were proposed and used by [27] to evaluate the effects of hydroelectric plants in the Ume River basin in northern Sweden.

Table 1. Description of Sub-daily hydrological indicators (SDHI). ${ }^{*}=$ indicators previously proposed and used by [27].

\begin{tabular}{|c|c|c|}
\hline Main SDHI Groups & $\begin{array}{l}\text { Descriptions of River } \\
\text { Regime (Indicators) }\end{array}$ & Units \\
\hline \multirow{9}{*}{ Group 1. Magnitude of sub-daily flows } & First quartile of the day & $\mathrm{m}^{3} \mathrm{~s}^{-1}$ \\
\hline & Second quartile of the day & $\mathrm{m}^{3} \mathrm{~s}^{-1}$ \\
\hline & Third quartile of the day & $\mathrm{m}^{3} \mathrm{~s}^{-1}$ \\
\hline & Fourth quartile of the day & $\mathrm{m}^{3} \mathrm{~s}^{-1}$ \\
\hline & 1-h-minimum flow & $\mathrm{m}^{3} \mathrm{~s}^{-1}$ \\
\hline & 3-h-minimum flow & $\mathrm{m}^{3} \mathrm{~s}^{-1}$ \\
\hline & 1-h-maximum flow & $\mathrm{m}^{3} \mathrm{~s}^{-1}$ \\
\hline & 3-h-maximum flow & $\mathrm{m}^{3} \mathrm{~s}^{-1}$ \\
\hline & Daily range * & $\mathrm{m}^{3} \mathrm{~s}^{-1}$ \\
\hline \multirow{2}{*}{ Group 2. Sub-daily flow pulse frequency } & Number of low pulses & $\mathrm{NP}_{\text {day }}{ }^{-1}$ \\
\hline & Number of high pulses & NP day ${ }^{-1}$ \\
\hline \multirow{3}{*}{ Group 3. Rate of change of sub-daily flows } & Number of reversals & $\mathrm{NR}_{\text {day }}{ }^{-1}$ \\
\hline & Rise rate & $\mathrm{m}^{3} \mathrm{~s}^{-1} \mathrm{~h}^{-1}$ \\
\hline & Fall rate & $\mathrm{m}^{3} \mathrm{~s}^{-1} \mathrm{~h}^{-1}$ \\
\hline \multirow{3}{*}{ Group 4. Duration of sub-daily flow regimes } & Duration of stability ${ }^{*}$ & $\mathrm{~h}_{\text {day }}{ }^{-1}$ \\
\hline & Duration high pulse * & $\mathrm{h}_{\text {day }}{ }^{-1}$ \\
\hline & Duration low pulse * & h day ${ }^{-1}$ \\
\hline
\end{tabular}




\subsubsection{Group 1. Magnitude of Sub-Daily Flows}

The "quartile flows of the day" parameter represents the median of the flows recorded during each quartile of a day, with the first quartile ranging from 0:00-5:59, followed by the second 6:00-11:59, third 12:00-17:59, and the fourth from 18:00-23:59. The output of this process will be four indicators that represent the magnitudes of flows in each of the quartiles, roughly corresponding to night, morning, afternoon, and evening. Thus, this identifies patterns of sub-daily hydrological changes to supplement the demands of energy production in the periods of the day.

Sub-daily extremes were assessed using the maximum and minimum flows within $1 \mathrm{~h}$ and $3 \mathrm{~h}$ time periods along with the daily range in flow rates. The hourly minimum and maximum flows are simply the minimum and maximum recorded hourly flow rate within a daily timeseries. To calculate the $3 \mathrm{~h}$ minimum and maximum flows, a three-hour moving average was first calculated, then the minimum and maximum values of the resulting $3 \mathrm{~h}$ averages were reported. The daily range indicator was calculated as the difference between the maximum and minimum hourly flow rate during a day.

\subsubsection{Group 2: Sub-Daily Flow Pulses Frequency}

Each time the flow rate falls outside of the 25 to $75 \%$ daily flow range, a pulse is recorded. A single pulse is considered to be the entire range of consecutive flow data outside of the 25 to $75 \%$ flow thresholds. The number of pulses below $25 \%$ is recorded as the number of low pulses while the number of pulses above $75 \%$ is recorded as the number of high pulses (Figure 2a). In the case shown in Figure 2a, there is a low pulse from 14:00 to 20:00 and a high pulse from 23:00 until midnight.
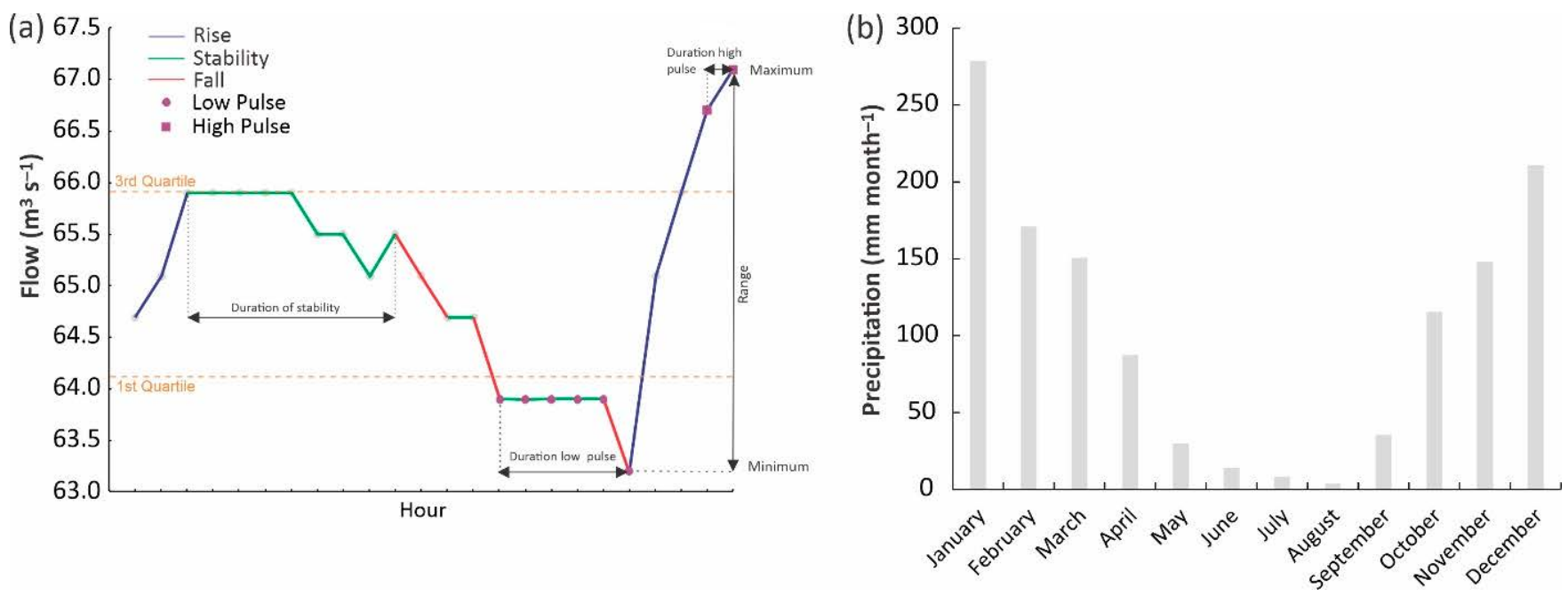

Figure 2. (a) Exemplary hydrograph for a single day with representation of select indicators; (b) Average monthly variation of precipitation in the city of Rondonópolis, which is within the Itiquira Basin, during the period from 1999 to 2015 (station $\mathrm{n}^{\circ}$ 83410; Source: BDMEP/INMET). 


\subsubsection{Group 3: Rate of Change of Sub-Daily Flows}

The rates of change quantify the speed of increase or decrease in flow rates per unit of time, as well as the number of times that the direction of change switches in the hydrograph. A change in flow rate was identified if a flow rate differed by more than $1 \%$ compared to the previous hourly flow rate. Successive hourly flow rates with changes greater than $1 \%$ in the same direction (increasing or decreasing) were grouped as a single change event. From there, the rise or recession was calculated as the difference between the initial and final flow rate of an event. The value of the largest dowries and recession events within a day are reported as the rise rate and fall rate (Figure 2a). For the recession, you can also see two events within a day.

A reversal occurs when there is a change in the direction of flow in the hydrograph. That is, when two successive change events, as previously defined, occur in opposite directions (i.e., a rise followed by a fall or a fall followed by a rise). The number of these reversals that occurred within a daily hydrograph are reported.

\subsubsection{Group 4: Duration of Sub-Daily Flow Regimes}

The duration of stability indicator quantifies the longest period of time that the flow remains relatively unchanged during the day. Because a threshold of $1 \%$ change in flow rate between hourly data was used, stability events are the time intervals that are not change events. This indicator is shown in Figure 2a; during the time series shown there were two periods in which the flow remained stable. The first period corresponds to a length of $8 \mathrm{~h}$ while the other period has a length of $4 \mathrm{~h}$. The indicator value for this time series is therefore $8 \mathrm{~h}$ (longest period).

The low and high pulse durations represent the longest time the flow remained either above the $75 \%$ threshold or below the $25 \%$ threshold on a given day. In the case of Figure $2 \mathrm{a}$ the duration of the low pulse was $5 \mathrm{~h}$ and the high pulse duration was $2 \mathrm{~h}$.

\subsection{Assessment of Hydrologic Change}

To quantify the hydrologic change caused by the operation of a hydroelectric facility, the sub-daily flow upstream and downstream of a facility was characterized by the 17 indicators. Based on the calculated indicators an assessment of the hydrologic change across the facility can be carried out in two stages.

The first stage is to determine which indicators are significantly altered across the reservoir. The Wilcoxon signed rank test was applied. This test compares the difference in rank-ordered paired values. The null hypothesis assumes that the difference between upstream and downstream data is zero. A significance level of $5 \%$ was used in this paper.

In the second stage, the values of each indicator, for the same day, were paired between the upstream and downstream for the quantification of the magnitude of the hydrologic alteration. The analysis method was adapted from the RVA (range of variability approach) developed by $[8,28]$. In this approach, a range of variability, determined by the 25 th and 75th percentiles of the hourly or sub-hourly values of the natural (upstream) conditions, are established for each indicator. The frequencies at which the indicators, under natural and altered (downstream) conditions, fall within this interval are then calculated separately. This relative change in frequency from natural to altered conditions is called the hydrologic change rate (HCR, Equation (1)). The advantage of using this method is that it controls for seasonal climatic variability (e.g., precipitation), isolating the effect caused exclusively by the hydroelectric plant, since the comparisons between inflow and outflow of the reservoir are under the same meteorological conditions.

$$
H C R=\frac{I n_{\text {natural }}-I n_{\text {altered }}}{I n_{\text {natural }}} \times 100
$$

where $I n_{\text {natural }}$ is the frequency of the hourly flow values found within the ranges of variability corresponding to the data under natural conditions and $I n_{\text {altered }}$ is the frequency of the hourly flow values found within the ranges of variability corresponding to the data 
under altered conditions. The impact levels related to each of the percentages obtained with the HCR values are categorized in Table 2.

Table 2. Impact levels for determining the category of hydrologic change in the watercourse.

\begin{tabular}{cc}
\hline Impact Level & Hydrologic Change \\
\hline Very low (VL) & $<25 \%$ \\
Low (L) & $25-50 \%$ \\
Medium (M) & $50-75 \%$ \\
High (H) & $>75 \%$ \\
\hline
\end{tabular}

\subsection{Study Area}

The utility of the proposed hydrologic indicators is shown using data from a sub-daily frequency hydrograph. For this case study, flow data from upstream and downstream of the Itiquira Hydroelectric Plant were used. The facility is located in the Itiquira Basin, whose drainage area is $33,900 \mathrm{~km}^{2}$, which corresponds to $9.36 \%$ of the Paraguay Hydrographic Basin (PHB). The PHB is characterized by two primary geologic and ecologic features, the upper plateau (Planalto) formed by the savanna (cerrado) biome and the lower Pantanal floodplain biome.

The climate of the region is characterized as hot and sub-humid, being defined by the Köppen classification as AW (tropical savanna with dry winter), with an average annual temperature of $24^{\circ} \mathrm{C}$, varying between a minimum of $13.6^{\circ} \mathrm{C}$ and maximum of $34.4^{\circ} \mathrm{C}$. The region has a marked seasonality, with two well defined seasons, rainy (October to April), in which $92.70 \%$ of rainfall occurs, and the dry (June to August) where only $2 \%$ of rainfall occurs. The average annual rainfall is $1247 \mathrm{~mm}$, with the maximum occurring in January $(278.52 \mathrm{~mm})$ and the minimum occurring in August $(3.79 \mathrm{~mm})$, as can be seen in Figure $2 \mathrm{~b}$.

The Itiquira HPP (hydroelectric power plant) was installed on the edge of the Planalto where it takes advantage of a 220 m elevation difference to generate power of $156 \mathrm{MW}$. Power generation is divided between two hydraulic turbines installed in series. The structure relies on an earthen dam with a maximum height of $15 \mathrm{~m}$ and a concrete spillway forming a 215 hectare reservoir. Water for power generation is diverted from the reservoir into a $4200 \mathrm{~m}$ channel (Figure 3). The flow then moves to the loading chamber and from there it passes through a forced conduit, taking advantage of a $90 \mathrm{~m}$ elevation difference while generating $61 \mathrm{MW}$ of power. The second circuit starts from the downstream rechannelization of the first power house. This channel travels $2350 \mathrm{~m}$ to a second loading chamber, and then to a forced conduit, and finally a second power house, which has an installed capacity of $95 \mathrm{MW}$. This second circuit takes advantage of the remaining drop of $130 \mathrm{~m}$. In the Itiquira HPP the route time in the reduced flow reach (RFR) is $2 \mathrm{~h}$ and the minimum flow that must be maintained in this section is $0.5 \mathrm{~m}^{3} \mathrm{~s}^{-1}$. 


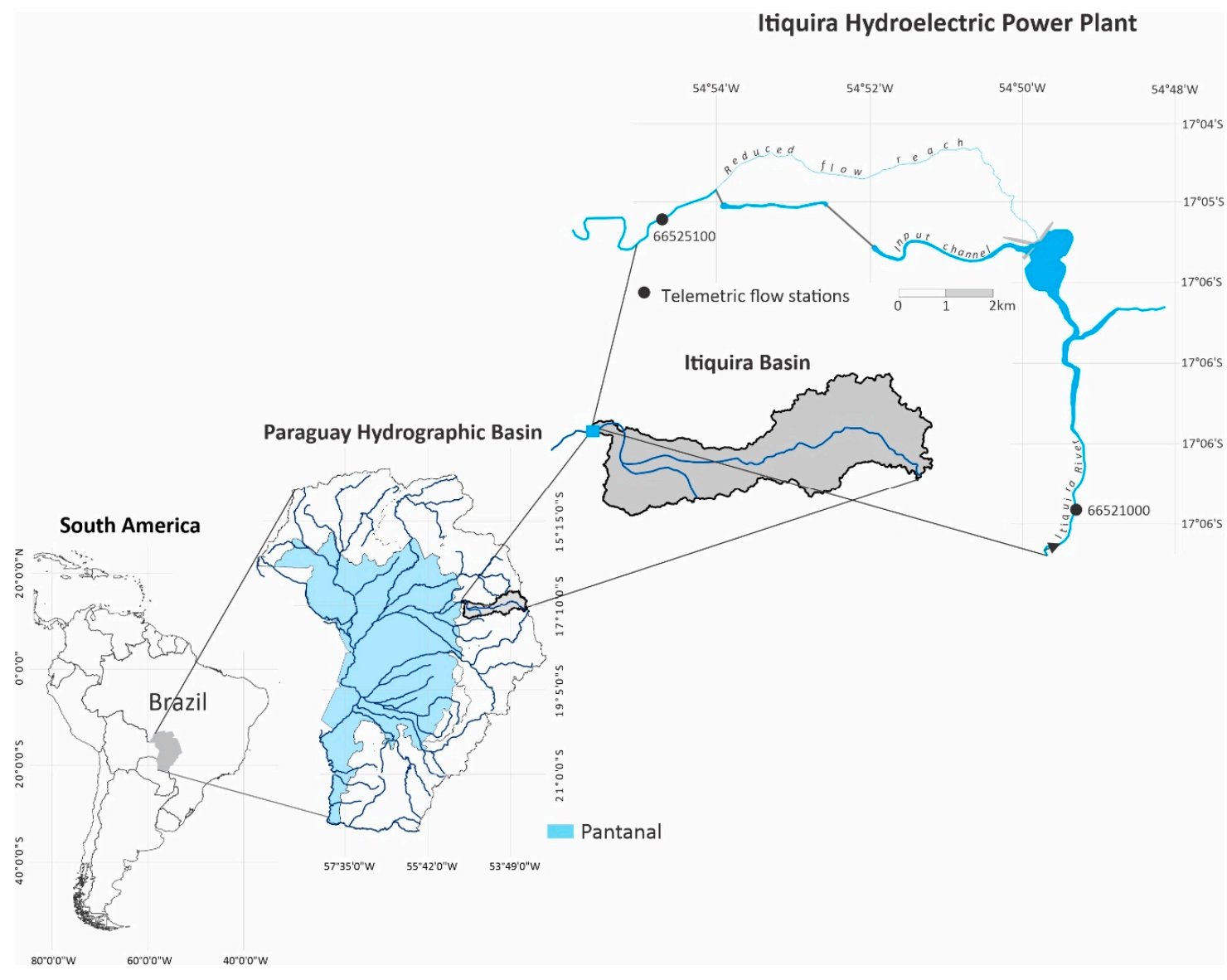

Figure 3. Location of Itiquira hydroelectric power plant and upstream and downstream monitoring stations.

\subsection{Database}

In this study, data from two telemetric flow stations maintained by the Brazilian National Water Agency were used (upstream from Itiquira HPP: 66521000 and downstream from Itiquira HPP: 66525100; Figure 4). The stations transmit hourly discharge measurements (Supplementary Materials). Both stations have been in continuous operation since 2 March 2015.
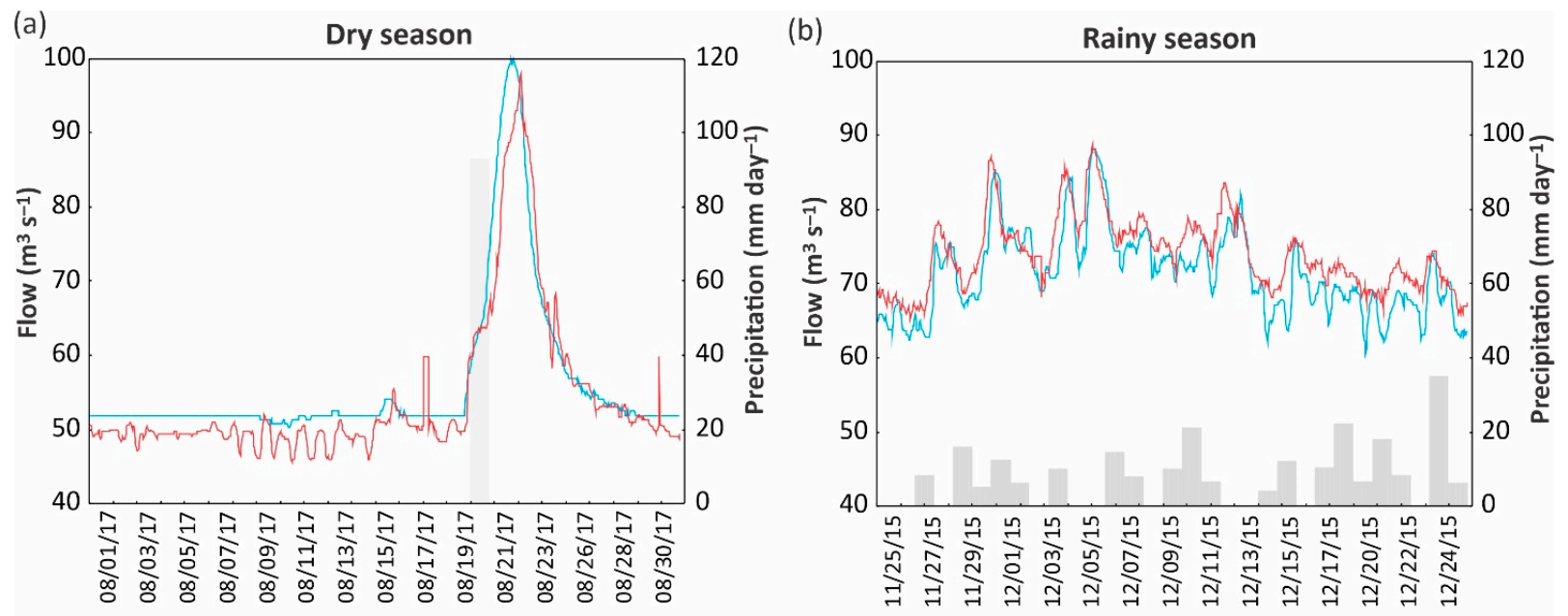

\footnotetext{
Upstream Downstream Precipitation
}

Figure 4. Hourly flows measured upstream and downstream from the Itiquira hydroelectric power plant with the respective daily precipitations for (a) dry season (01/08/2017 to 08/31/2017), and (b) rainy season (11/25/2015 to 12/25/2015). 
For the identification and quantification of the effects of the hydroelectric operation on the daily hydrologic regime downstream from the project, two temporally matched series (upstream and downstream) were selected. Data series were chosen in which both gages had 31 consecutive days without failure. One pair of hydrographs was chosen for the dry season and one pair of hydrographs was chosen for the wet season. The selected time series spanned 00:00 on 08/01/2017 until 23:00 on 08/31/2017 for the dry season, and from 00:00 on 11/25/2015 until 23:00 on 12/25/2015 for the rainy season.

The comparison of temporally matched data just upstream and downstream from the hydroelectric facility allows for isolation of the reservoir effect and controlling influences of climatic variability, as well as changes in land use and development within the basin. This design allows robust conclusions when compared to analyzes of pre and post impact series, since it can be applied in short duration and non-stationary series [2].

\section{Results}

\subsection{Characterization of the Hydrologic Regime}

During the dry season the hydrology upstream from the Itiquira HPP is predominantly base flow. This season and location are characterized by low variability in flow with very rare hydrographic pulses occurring within days of the precipitation event. During this period, the average flow rate was $51.9 \mathrm{~m}^{3} \mathrm{~s}^{-1}$, with quartiles between 51.9 and $53.6 \mathrm{~m}^{3} \mathrm{~s}^{-1}$. In addition, a rainfall event occurred with a cumulative depth of $85.8 \mathrm{~mm}$ in 21 August, which resulted in an upstream flow pulse of $99.9 \mathrm{~m}^{3} \mathrm{~s}^{-1}$ (Figure 4a). The general hydrologic shape and peak characteristics were maintained in the downstream regime while increased variability downstream from the facility can be observed during dry periods.

In the rainy season, the average flow rate upstream from the Itiquira HPP was $70.7 \mathrm{~m}^{3} \mathrm{~s}^{-1}$ with quartiles between 67.5 and $75.0 \mathrm{~m}^{3} \mathrm{~s}^{-1}$. During this period, there is a greater variability of flow rates due to recurrent precipitation events, which totaled $353.9 \mathrm{~mm}$ across the 31 days (Figure $4 \mathrm{~b}$ ).

\subsection{Sub-Daily Hydrologic Indicators (SDHI)}

The indicators for each hydrograph are presented in Table 3. The indicators show differences in magnitude both from the upstream to downstream regions and between seasons. Upstream from the Itiquira HPP, the Itiquira River has low variability in the sub-daily flows during the dry season, as shown by the indicators. This low variability is especially pronounced in the daily range $\left(0.6 \mathrm{~m}^{3} \mathrm{~s}^{-1}\right)$, number of reversals (1 per day) and duration of stability $\left(20 \mathrm{~h} \mathrm{day}^{-1}\right)$. The operation of the Itiquira HPP changes the natural sub-daily variability by increasing the daily range $\left(4.4 \mathrm{~m}^{3} \mathrm{~s}^{-1}\right)$, the number of reversals (four per day), and reducing the duration of stability $\left(8 \mathrm{~h} \mathrm{day}^{-1}\right)$. In contrast, during the rainy season, when naturally the hydrological variability is greater, the operation of the dam changes little in this pattern. This can be seen in the similarity of the indicators between the upstream and downstream, with the exception of the daily range, which decreased from 7.9 to $5.1 \mathrm{~m}^{3} \mathrm{~s}^{-1}$.

During the dry season, of the 17 indicators evaluated, nine (53\%) resulted in hydrologic change rates classified as high, six as low, and two as very low (Table 3). During this period, only the high pulse flow magnitude indicators were not significantly different between the upstream and downstream regions from the hydroelectric facility.

During the rainy season, most of the hydrologic change rate indicators were classified as very low (12), followed by low (three), and one medium and one high (Table 3). A difference from the dry season results was that, during the rainy season, there was no pattern in relation to the direction of the hydrologic change rate, since five indicators showed an increase and seven showed a reduction in the frequency of occurrence of values. Despite the reduction in the magnitude of the hydraulic change rates, the Wilcoxon test showed that, even during the rainy season, the flow upstream from the reservoir was significantly different than the flow downstream from the reservoir according to 12 of the 
17 indicators. Only the rise rate, fall rate, duration of stability, duration of the low pulses, and number of low pulses parameters were not significantly altered (Table 3 ).

Table 3. Characteristics of the hydrologic regime on a sub-daily scale across the Itiquira hydroelectric power plant (upstream and downstream) during the dry and rainy seasons. * Significant values for the Wilcoxon paired test $(p \leq 0.05)$. Md-Median, QL-Quartile, HCR—Hydrologic Change Rate, VL-Very Low, L-Low, M-Medium, H—High.

\begin{tabular}{|c|c|c|c|c|c|c|c|c|c|c|}
\hline \multirow{3}{*}{ Indicator } & \multicolumn{5}{|c|}{ Dry Season } & \multicolumn{5}{|c|}{ Rainy Season } \\
\hline & \multicolumn{2}{|c|}{ Upstream } & \multicolumn{2}{|c|}{ Downstream } & \multirow[t]{2}{*}{ HCR } & \multicolumn{2}{|c|}{ Upstream } & \multicolumn{2}{|c|}{ Downstream } & \multirow[t]{2}{*}{ HCR } \\
\hline & Md & QL 25/75 & Md & QL 25/75 & & Md & QL 25/75 & Md & QL 25/75 & \\
\hline \multicolumn{11}{|c|}{ Group 1. Magnitude of Sub-Daily Flows } \\
\hline 1st quartile $\left(\mathrm{m}^{3} \mathrm{~s}^{-1}\right)$ & 51.9 & $51.9 / 53.1$ & 50.7 & $50.0 / 52.9$ & $85(\mathrm{H}) *$ & 72.6 & $68.8 / 75.8$ & 73.5 & $70.6 / 77.2$ & $0(\mathrm{VL}) *$ \\
\hline 2nd quartile $\left(\mathrm{m}^{3} \mathrm{~s}^{-1}\right)$ & 51.9 & $51.9 / 52.9$ & 50 & $49.4 / 52.5$ & $95(\mathrm{H}) *$ & 70.9 & $67.5 / 74.9$ & 73.8 & $70.8 / 77.2$ & $-13(\mathrm{VL}) *$ \\
\hline 3rd quartile $\left(\mathrm{m}^{3} \mathrm{~s}^{-1}\right)$ & 51.9 & $51.9 / 53.5$ & 49.7 & $48.5 / 53.0$ & $90(\mathrm{H}) *$ & 69.3 & $64.5 / 73.7$ & 72.65 & $69.3 / 76.1$ & $-13(\mathrm{VL}) *$ \\
\hline 4th quartile $\left(\mathrm{m}^{3} \mathrm{~s}^{-1}\right)$ & 51.9 & $51.9 / 53.9$ & 49.7 & $48.8 / 53.0$ & $90(\mathrm{H}) *$ & 71.8 & $67.5 / 75.1$ & 73.2 & $70.7 / 77.1$ & $-13(\mathrm{VL}) *$ \\
\hline $\begin{array}{l}1 \mathrm{~h} \text { minimum } \\
\left(\mathrm{m}^{3} \mathrm{~s}^{-1}\right)\end{array}$ & 51.9 & $51.9 / 52.2$ & 49.1 & $47.6 / 51.2$ & $100(\mathrm{H}) *$ & 67.9 & $63.4 / 71.6$ & 70.9 & $68.4 / 74.1$ & $-18(\mathrm{VL})$ * \\
\hline $\begin{array}{l}3 \mathrm{~h} \text { minimum } \\
\left(\mathrm{m}^{3} \mathrm{~s}^{-1}\right)\end{array}$ & 51.9 & $51.9 / 54.6$ & 51.4 & $50.5 / 59.8$ & $80(\mathrm{H}) *$ & 75.4 & $70.3 / 78.2$ & 76.1 & $73.2 / 79.5$ & 11. $(\mathrm{VL})$ * \\
\hline $\begin{array}{l}1 \mathrm{~h} \text { maximum } \\
\left(\mathrm{m}^{3} \mathrm{~s}^{-1)}\right.\end{array}$ & 51.9 & $51.9 / 52.2$ & 49.3 & $47.8 / 51.3$ & $100(\mathrm{H})$ & 67.9 & $63.7 / 71.7$ & 70.9 & $68.8 / 74.2$ & $-21(\mathrm{VL})$ * \\
\hline $\begin{array}{c}3 \mathrm{~h} \text { maximum } \\
\left(\mathrm{m}^{3} \mathrm{~s}^{-1}\right)\end{array}$ & 51.9 & $51.9 / 54.5$ & 51.27 & $50.1 / 57.8$ & $80(\mathrm{H})$ & 74.9 & $70.1 / 78.1$ & 75.7 & $72.7 / 79.4$ & $-6(\mathrm{VL}) *$ \\
\hline Daily range $\left(\mathrm{m}^{3} \mathrm{~s}^{-1}\right)$ & 0.6 & $0 / 1.9$ & 4.4 & $2.3 / 6.1$ & $78(\mathrm{H}) *$ & 7.9 & $3.9 / 10.0$ & 5.1 & $3.4 / 7.2$ & $-6(\mathrm{VL}) *$ \\
\hline \multicolumn{11}{|c|}{ Group 2. Sub-Daily Flow Pulses Frequency } \\
\hline $\begin{array}{l}\text { Number of high } \\
\text { pulses (NP day }{ }^{-1} \text { ) }\end{array}$ & 0 & $0 / 1$ & 1 & $1 / 1$ & $17(\mathrm{VL}) *$ & 1 & $1 / 1$ & 1 & $1 / 2$ & $25(\mathrm{~L}) *$ \\
\hline $\begin{array}{l}\text { Number of low } \\
\text { pulses }\left(\mathrm{NP} \text { day }^{-1} \text { ) }\right.\end{array}$ & 0 & $0 / 1$ & 1 & $1 / 1$ & $13(\mathrm{VL}) *$ & 1 & $1 / 2$ & 2 & $1 / 2$ & $3(\mathrm{VL})$ \\
\hline \multicolumn{11}{|c|}{ Group 3. Rate of Change of Sub-Daily Flows } \\
\hline $\begin{array}{c}\text { Number of reversals } \\
\left(\mathrm{NR}_{\text {day }}{ }^{-1}\right)\end{array}$ & 1 & $0 / 4.5$ & 5 & $04 / 06$ & $39(\mathrm{~L})$ * & 6 & $05 / 07$ & 8 & $7 / 9.5$ & $50(\mathrm{M}) *$ \\
\hline Rise rate $\left(\mathrm{m}^{3} \mathrm{~s}^{-1} \mathrm{~h}^{-1}\right)$ & 0 & $0 / 0.6$ & 0.68 & $0.4 / 0.9$ & $36(\mathrm{~L}) *$ & 0.98 & $0.8 / 1.26$ & 1.1 & $1 / 1.46$ & $-7(\mathrm{VL})$ \\
\hline Fall rate $\left(\mathrm{m}^{3} \mathrm{~s}^{-1} \mathrm{~h}^{-1}\right)$ & 0 & $0 / 0.6$ & 0.65 & $0.4 / 0.9$ & $38(\mathrm{~L}) *$ & 0.89 & $0.7 / 1.07$ & 1.1 & $0.7 / 1.2$ & $46(\mathrm{~L})$ \\
\hline \multicolumn{11}{|c|}{ Group 4. Duration of Sub-Daily Flows } \\
\hline $\begin{array}{l}\text { Duration of stability } \\
\left(\mathrm{h} \mathrm{day}^{-1}\right)\end{array}$ & 20 & $8.0 / 24.0$ & 8 & $6.0 / 10.5$ & $29(\mathrm{~L})$ * & 5 & $3.0 / 6.5$ & 5 & $3.5 / 6.5$ & $14(\mathrm{VL})$ \\
\hline $\begin{array}{l}\text { Duration high pulse } \\
\qquad\left(\mathrm{h} \mathrm{day}^{-1}\right)\end{array}$ & 0 & $0 / 2.5$ & 4 & $3.0 / 5.5$ & $78(\mathrm{~L}) *$ & 5 & $4.0 / 6.0$ & 4 & $2.0 / 5.0$ & $23(\mathrm{~L}) *$ \\
\hline $\begin{array}{l}\text { Duration low pulse } \\
\quad\left(\mathrm{h} \mathrm{day}^{-1}\right)\end{array}$ & 0 & $0 / 2.5$ & 4 & $2.0 / 5.5$ & $\begin{array}{c}-162(\mathrm{~L}) \\
*\end{array}$ & 5 & $3.0 / 6.0$ & 3 & $2.0 / 5.0$ & $-83(\mathrm{H})$ \\
\hline
\end{tabular}

\section{Discussion}

Analyses carried out by [19] identified the effects of the operation of hydroelectric plants in several basins in Brazil, among them the Itiquira HPP, using the IHA metrics associated with daily data. Using the hydraulic change rate, they classified the flow changes across the dam as low magnitude $(\mathrm{HCR}=15 \%)$. Adopting the same calculation criteria as [19], but with sub-daily parameters, we report a HCR of $60.0 \%$ for the dry season and a $\mathrm{HCR}$ of $11.7 \%$ for the rainy season. It is apparent from these divergent results that while 
the hydrology at daily and seasonal scales has changed very little, at the sub-daily scale there are substantial differences during the dry season.

The hourly fluctuations in flow observed downstream from the Itiquira HPP during the dry season are likely due to intermittent turbine operations. To operate the turbines, a minimum flow and pressure head is required. During the rainy season there is sufficient water to run all turbines continuously. However, during the dry season, one or more of the turbines may be operated in a cyclical fashion such that when a turbine is shut down, the reservoir is allowed to fill. Once the reservoir is sufficiently full, the turbine is restarted causing the reservoir to drain. During these cyclical operations the downstream hydrograph experiences periodic decreases in flow (when the reservoir is filling) followed by periods of increased flow (when the water is released through the turbines).

According to [29], rivers with stable flow characteristics are impacted to a greater extent by the operations of hydroelectric plants. Such results appear to be confirmed by this study since the number and magnitude of change in indicators was larger during the stable dry season than the more variable rainy season. The availability of sub-daily data is still a limitation for the assessment of hydroelectric dams within the PHB and many parts of the world. While the 31-day data sets are relatively short, these selections of dry and rainy seasons represent the extremes of the seasonal cycle of the Pantanal; transitional flow seasons can be expected to show intermediate results between these two datasets.

The cyclical turbine operation can be inferred in indicators such as the daily range, since short duration low and high pulses that did not exist before now occur. Rates of ascent and recession due to the abrupt activation and deactivation of turbines occur may also be affected. Many diversion channel hydroelectric facilities reduce the pass-through flow during the night, since the energy demand is low. With this maneuver, the operator expects the reservoir to fill at night but drain during part of the day. However, the Itiquira HPP reservoir is mostly silted, leaving little useable storage volume available, so the quartile indicators did not present large changes between the quartiles as might have been expected [21].

The Itiquira HPP is one of 47 hydroelectric facilities operating in the PHB. The operational effects of these facilities are felt by the riverside population of the region who report great variations in the water levels, with occurrence of "droughts and floods in the same day" [30]. There are also reports of fishermen who have witnessed a reduction in fish catch during the times when there are high pulses derived from the operations of the turbines; a fact also recorded by [31] in the Amazon Basin.

To minimize these impacts, a "Manual of Procedure and Operation" was launched by the Brazilian National Electric System Operator (ONS), which includes four facilities located in the PHB where operational guidelines are defined (this manual entered into force in October 2017). For the Itiquira HPP, it is now required that in the dry season there can be no downstream variations greater than $10 \mathrm{~m}^{3} \mathrm{~s}^{-1}$ during a period of $2 \mathrm{~h}$. In addition, it was required that the minimum downstream flow rate not be less than $40 \mathrm{~m}^{3} \mathrm{~s}^{-1}$, so as not to impair the ichthyofauna and the fishery in the region. In the presented data, it was verified that these restrictions have been obeyed in the operation of the enterprise (Table 3), even though enforcement of the manual commenced after the period studied.

It should be noted that ONS only regulates hydroelectric plants with a power greater than $30 \mathrm{MW}$ and, despite the limitations imposed on Itiquira HPP, it has no legal responsibility for the overall management of water resources. In Brazil, small hydroelectric plants do not undergo any type of operational regulation of flows for environmental protection, as is the case in some countries in Europe and North America [32].

Our findings do not allow us to directly link hydrological change to ecological impacts downstream of dams. However, changes in hydrological indicators at the sub-daily scale show that the downstream hydrological regime has changed where previous studies had shown little variation. Ref. [33] proposes that when it is not possible to establish links between hydrological alteration and ecological modifications, a presumptive limit should be adopted, and based on a review of previous studies, they recommended that less than 
$20 \%$ of indicators should be allowed to change. By this criterion, we can say that the hydrological changes in the dry season are above acceptable levels.

In December 2018, in the stretch immediately downstream from the Itiquira HPP, the death of about 400 large fish (Pseudoplatystoma fasciatum) was reported by stranding during the breeding period [34]. Cross referencing the date of this record with the flow of the Itiquira River, we can infer that mortality was caused by two hydropeaking events, when the flow increased from 73.35 to $99.7 \mathrm{~m}^{3} \mathrm{~s}^{-1}$ in the interval of one hour, and then reduced to $62.1 \mathrm{~m}^{3} \mathrm{~s}^{-1}$ in ten hours, before rising again to $91.4 \mathrm{~m}^{3} \mathrm{~s}^{-1}$ in seven hours (Figure 5).

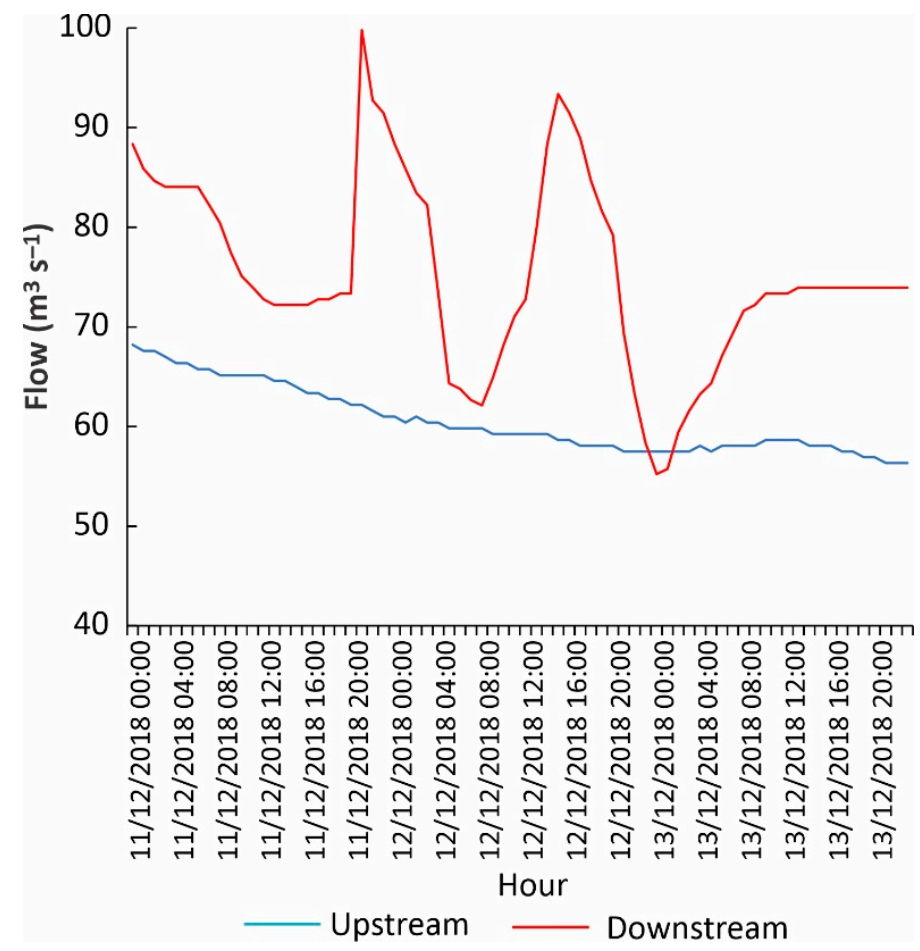

Figure 5. Hydropeaking causes the death of fish downstream of the Itiquira hydroelectric power plant.

Sudden variations in the river level, such as those recorded in the dry season, can negatively affect fishing. Fishermen from the Madeira River (Amazon Basin-Brazil), argue that the increase in the irregularity and unpredictability of the flow regime caused by hydropeaking negatively affects fish catches [31]. For the rivers that form the Pantanal, the ecological effects of hydropeaking on the behavior of fish remains unknown and deserves further investigation.

\section{Conclusions}

This study shows that hydropeaking events occurring downstream from a hydroelectric run-of-river facility do significantly impact proposed sub-daily hydrologic indicators. The evaluations carried out at the Itiquira HPP presented two distinct scenarios: the rainy season, where $94 \%$ (16) the indicators showed low change rates due to the presence of the reservoir-with only two indicators presenting a medium and high hydrologic change rate (number of flow reversals and duration low pulse)—and in the dry season, in which 53\% (9) of the indicators showed high hydrologic change rates.

This finding is the first piece of evidence in the basin that shows a small run-of-theriver reservoir is causing significant hydrological changes over the sub-daily regime of the river, which may affect the region's energy planning. This change in energy planning may have come to fruition because the justification for the installation of the 138 proposed facilities in the basin is that, since they are formed mostly of small hydroelectric plants $(<30 \mathrm{MW})$ with run-of-river operation, they would not be likely to change the regime of the Pantanal rivers. The installation of hydrometric monitoring stations downstream of 
hydroelectric plants, with high frequency measurements and adequate maintenance, to avoid failures, is an important instrument for understanding, and therefore mitigating and controlling impacts. This instrument associated with metrics that characterize the sub-daily hydrological regime allows the development of operational protocols that reduce the occurrence of hydropeaking and its undesirable effects in stretches downstream. Finally, we recommend that the Brazilian environmental agencies, when defining environmental flows for rivers with high ecological importance, also consider sub-daily variations, as is the case in some countries in Europe and North America [30]. In this way we will also be contributing to the achievement of goal six (Clean Water and Sanitation) of the Sustainable Development Goals and to the efficient management of water.

Supplementary Materials: Hydrological data are available at http:/ / www.snirh.gov.br/hidrotelemetria / Mapa.aspx.

Author Contributions: This study was conceived and carried out by I.F.-C., P.G. and P.Z., C.C.B.-C., I.F.-C. and R.L.B. developed the computational routine for the high frequency time series analysis. Field work and data analysis were conducted by C.C.B.-C., I.F.-C., L.d.S.R. and H.M.T. The paper was written mainly by C.C.B.-C., H.M.T. and I.F.-C. All authors have read and agreed to the published version of the manuscript.

Funding: Funding was provided by the Foundation for Research Support in the State of Mato Grosso (FAPEMAT Cas 0249639/2017), and the Brazilian National Council for Scientific and Technological Development (CNPq, Case 435543/2018-0). Financial, logistical and technical support was provided by the and the Federal University of Mato Grosso (PROPeq/PROAD-UFMT).

Data Availability Statement: Not Applicable.

Conflicts of Interest: The authors declare no conflict of interest.

\section{References}

1. Gaudard, L.; Avanzi, F.; Michele, C.D. Seasonal aspects of the energy-water nexus: The case of a run-of-the-river hydropower plant. Appl. Energy 2018, 210, 604-612. [CrossRef]

2. Fantin-Cruz, I.; Pedrollo, O.; Girard, P.; Zeilhofer, P.; Hamilton, S.K. Effects of a diversion hydropower facility on the hydrological regime of the Correntes River, a tributary to the Pantanal floodplain, Brazil. J. Hydrol. 2015, 531, 810-820. [CrossRef]

3. Kelly-Richards, S.; Silber-Coats, N.; Crootof, A.; Tecklin, D.; Bauer, C. Governing the transition to renewable energy: A review of impacts and policy issues in the small hydropower boom. Energy Policy 2017, 101, 251-264. [CrossRef]

4. Poff, N.L.; Allan, J.D.; Bain, M.; Karr, J.R.; Prestegaard, K.L.; Richter, B.D.; Stromberg, J.C. The Natural Flow Regime: A paradigm for river conservation and restoration. BioScience 1997, 47, 769-784. [CrossRef]

5. Hart, D.D.; Finelli, C.M. Physical-Biological Coupling in Streams: The Pervasive Effects of Flow on Benthic Organisms. Annu. Rev. Ecol. Syst. 1999, 30, 363-364. [CrossRef]

6. Bunn, S.E.; Arthington, A.H. Basic Principles and Ecological Consequences of Altered Flow Regimes for Aquatic Biodiversity. Environ. Manag. 2002, 30, 492-507. [CrossRef]

7. Richter, B.D.; Baumgartner, J.V.; Powell, J.; Braun, D.P. A Method for Assessing Hydrologic Alteration within Ecossystem. Conserv. Biol. 1996, 10, 1163-1174. [CrossRef]

8. Richter, B.; Baumgartner, J.; Braun, D.P.; Powell, J. A spatial assessment of hydrologic alteration within a river network. Regul. Rivers Res. Manag. 1998, 14, 329-340. [CrossRef]

9. Ashraf, F.B.; Haghighi, A.T.; Riml, J.; Alfredsen, K.; Koskela, J.J.; Kløve, B. Changes in short term river flow regulation and hydropeaking in Nordic rivers. Sci. Rep. 2018, 8, 17232. [CrossRef]

10. Zimmerman, J.K.; Letcher, B.H.; Nislow, K.H.; Lutz, K.A.; Magilligan, F.J. Determining the effects of dams on subdaily variation in river flows at a whole-basin scale. River Res. Appl. 2009, 26, 1246-1260. [CrossRef]

11. Meile, T.; Boillat, J.-L.; Schleiss, A.J. Hydropeaking indicators for characterization of the Upper-Rhone River in Switzerland. Aquat. Sci. 2011, 73, 171-182. [CrossRef]

12. Haas, N.A.; O'Connor, B.L.; Hayse, J.W.; Bevelhimer, M.S.; Endreny, T.A. Analysis of Daily Peaking and Run-of-River Operations with Flow Variability Metrics, Considering Subdaily to Seasonal Time Scales. J. Am. Water Resour. Assoc. 2014, 50, 1622-1640. [CrossRef]

13. Sauterleute, J.F.; Charmasson, J. A computational tool for the characterisation of rapid fluctuations in flow and stage in rivers caused by hydropeaking. Environ. Model. Softw. 2014, 55, 266-278. [CrossRef]

14. Bevelhimer, M.S.; McManamay, R.A.; O'Connor, B. Characterizing Sub-Daily Flow Regimes: Implications of Hydrologic Resolution on Ecohydrology Studies. River Res. Appl. 2015, 31, 867-879. [CrossRef] 
15. Carolli, M.; Vanzo, D.; Siviglia, A.; Zolezzi, G.; Bruno, M.C.; Alfredsen, K. A simple procedure for the assessment of hydropeaking flow alterations applied to several European streams. Aquat. Sci. 2015, 77, 639-653. [CrossRef]

16. Junk, W.J.; Cunha, C.N. Pantanal: A large South American wetland at a crossroads. Ecol. Eng. 2005, 24, 291-401. [CrossRef]

17. Agência Nacional de Águas. Conjuntura dos Recursos Hídricos no Brasil 2018: Informe Annual; 2018. Available online: https: //arquivos.ana.gov.br/portal/publicacao/Conjuntura2018.pdf (accessed on 16 January 2021).

18. Collischonn, W.; Paz, A.R.; Melo, M.M.M.; Jardim, P.F. Potenciais Impactos de Barragens Sobre o Regime Hidrológico nos Rios da RH Paraguai. Elaboração de Estudos de Avaliação dos Efeitos da Implantação de Empreendimentos Hidrelétricos na Região Hidrográfica do Rio Paraguai. Agência Nac. Águas Brasilia (DF). 2019. Available online: https: / /www.ana.gov.br/gestao-da-agua / planejamento-dos-recursos-hidricos/plano-de-recursos-hidricos-rio-paraguai/estudos-de-avaliacao-dos-efeitos-da-implantacaode-empreendimentos-hidreletricos (accessed on 3 September 2019).

19. Timpe, K.; Kaplan, D. The changing hydrology of a dammed Amazon. Sci. Adv. 2017, 3, e1700611. [CrossRef]

20. Ho, L.T.; Goethals, P.L. Opportunities and challenges for the sustainability of lakes and reservoirs in relation to the Sustainable Development Goals (SDGs). Water 2019, 11, 1462. [CrossRef]

21. Fantin-Cruz, I.; de Oliveira, M.D.; Campos, J.A.; de Campos, M.M.; de Souza, R.L.; Mingoti, R.; de Souza, R.L.; Pedrollo, O.; Hamilton, S.K. Further Development of Small Hydropower Facilities Will Significantly Reduce Sediment Transport to the Pantanal Wetland of Brazil. Front. Environ. 2020, 8, 577748. [CrossRef]

22. Couto, T.B.; Olden, J.D. Global proliferation of small hydropower plants-Science and policy. Front. Ecol. Environ. 2018, 16, 91-100. [CrossRef]

23. Tharme, R.E. A global perspective on environmental flow assessment: Emerging trends in the development and application of environmental flow methodologies for rivers. River Res. Appl. 2013, 19, 397-441. [CrossRef]

24. Mathews, R.; Richter, B.D. Application of the indicators of hydrologic alteration software in environmental flow setting. J. Am. Water Resour. Assoc. 2013, 43, 1400-1413. [CrossRef]

25. Archer, D.; Newson, M. The use of indices of flow variability in assessing the hydrological and instream habitat impacts of upland afforestation and drainage. J. Hydrol. 2002, 268, 244-258. [CrossRef]

26. Jardim, P.F.; Melo, M.M.M.; Ribeiro, L.C.; Collischonn, W.; Paz, A.R. Modeling Assessment of Large-Scale Hydrologic Alteration in South American Pantanal Due to Upstream Dam Operation. Front. Environ. 2020, 8, 15. [CrossRef]

27. Bejarano, M.D.; Sordo-Ward, Á.; Alonso, C.; Nilsson, C. Characterizing effects of hydropower plants on sub-daily flow regimes. J. Hydrol. 2017, 550, 186-200. [CrossRef]

28. Richter, B.; Baumgartner, J.; Wigington, R.; Braun, D. How much water does a river need? Freshw. Biol. 1997, 37, 231-249. [CrossRef]

29. Alonso, C.; Román, A.; Bejarano, M.D.; de Jalon, D.G.; Carolli, M. A graphical approach to characterize sub-daily flow regimes and evaluate its alterations due to hydropeaking. Sci. Total Environ. 2017, 574, 532-543. [CrossRef]

30. Ferrite, G.; Nicola, R.; Calheiros, D. O Dia que o Rio Secou. 2014. Available online: https:/ / www.youtube.com/watch?v=9mlU2 IYrJ6c (accessed on 14 July 2019).

31. Santos, R.E.; Pinto-Coelho, R.M.; Fonseca, R.; Simões, N.R.; Zanchi, F.B. The decline of fisheries on the Madeira River, Brazil: The high cost of the hydroelectric dams in the Amazon Basin. Fish. Manag. Ecol. 2018, 25, 380-391. [CrossRef]

32. Moreira, M.; Hayes, D.S.; Boavida, I.; Schletterer, M.; Schmutz, S.; Pinheiro, A. Ecologically-based criteria for hydropeaking mitigation. A review. Sci. Total Environ. 2019, 657, 508-1522. [CrossRef]

33. Richter, B.D.; Davis, M.M.; Apse, C.; Konrad, C. A presumptive standard for environmental flow protection. River Res. Appl. 2012, 28, 1312-1321. [CrossRef]

34. G1 Mato Grosso. Usina Hidrelétrica é Suspeita de Provocar Morte de Peixes no Rio Itiquira em MT. 2018. Available online: https://g1.globo.com/mt/mato-grosso/noticia/2018/12/19/usina-hidreletrica-e-suspeita-de-provocar-morte-de-peixesno-rio-itiquira-em-mt.ghtml (accessed on 7 November 2019). 